\title{
METHOD OF JUSTIFICATION OF MACHINE PARTS HARDENING MODES
}

\author{
Alexander Pastukhov, Olga Sharaya, Eugeny Timashov, Dmitriy Bakharev \\ Belgorod State Agricultural University named after V. Gorin, Russia \\ pastukhov_ag@mail.ru, sharay61@mail.ru, timachov@mail.ru, baharevdn_82@mail.ru
}

\begin{abstract}
Based on an overview of methods for hardening and restoring parts of agricultural machines, it has been found that the methods currently used are highly labour intensive and are not well suited for hardening the cutting edge of tillage machine discs. A method of electromechanical hardening of ploughshare discs due to simultaneous thermal action and plastic deformation is disclosed. Electromechanical hardening modes are justified on the example of standard cylindrical samples. The developed technique contains the following stages: determining the steel grade of a part; planning of the experiment based on the plan of the full two-factor three-level experiment with selection of influences and response function; experimental hardening of laboratory samples at the installation; microstructural analysis of hardened samples; numerical processing of experiment results. Based on the optical emission analysis, it was found that the samples are made of steel $65 \mathrm{G}$. The factors of influence are: current strength $X_{1}\left(I_{r}\right)=800 \ldots 1200$ A on the reinforcing tool in the form of a roller and the pressing force $X_{2}\left(F_{k}\right)=100 \ldots 300 \mathrm{~N}$ of the tool to the part. The hardness of the surface layer Y(HRC) is adopted as the response function. Microstructural analysis showed that a layer consisting of several zones was formed on the hardened surface of the sample: white, light non-flowing and dark martensitic, passing into the ferrite-pearlite structure of the base. On the basis of multiple regression analysis, an empirical mathematical model is obtained and its graphical interpretation in the studied area of factors values is given. According to the criterion of providing wear resistance of working edges of disks, maximum hardness is achieved at current strength $X_{1}\left(I_{r}\right)=1060$ A and force $X_{2}\left(F_{k}\right)=210 \mathrm{~N}$ in the contact zone. Developed technique and tested modes of electromechanical hardening are suitable for development of process of hardening of disk ploughshares of grain-grass seeders.
\end{abstract}

Keywords: hardening, sample, modes, microstructure, hardness, optimization.

\section{Introduction}

The development of agriculture in the European area in the 21st century is characterized by ensuring a stable growth in the quality and production of agricultural products, creating conditions for the development of scientific and technical activities and obtaining the results necessary to create technologies that ensure the independence and competitiveness of agro-industrial products. In this regard, improving the quality and operational reliability of agricultural machinery is one of the most important issues [1].

In the case of working bodies of agricultural machines, the disturbance of operability is mainly due to the mechanical wear of the surface layer of the working edges. Therefore, the issue of increasing the wear resistance of the working edges of parts by hardening, for example, the working elements of cultivators and plows, discs of traps and harrows, as well as discs of ploughshares of sowing machines is especially relevant [2; 3]. In the operation of sowing machines, in particular, grain-weeding seeders SZT$3,6 \mathrm{~A}$, ploughshare discs undergo uneven wear of cutting edges along the periphery of the disc, while reducing the quality of sowing, increasing the traction resistance of the unit and fuel consumption, which negatively affects the yield, gross harvest and cost of grain [3].

In practice, in agricultural machinery, methods of combined processing of machine parts are widely introduced, for example, by combining power and temperature effects during time exposure, for example, laser, electromechanical and other types of processing [4]. The most preferred method is electromechanical processing taking into account technological and cost criteria, but the issues of theoretical and experimental substantiation of treatment modes taking into account operational properties of working surfaces have not been fully solved [4;5].

The purpose of the work is the experimental development of electromechanical hardening modes on laboratory cylindrical samples for the detailed development of the technological process of hardening the ploughshares disks.

To achieve the goal, the following objectives are set:

- to analyze how to harden thin-walled parts of the "disc" type;

- to substantiate the selection of electromechanical hardening modes;

- to conduct experimental studies of the effect of hardening regimes on hardness. 


\section{Materials and methods}

The object of experimental studies is a cylindrical sample in the amount of 10 units, made of steel 65G GOST 14959-2016 in normalized state, which corresponds to foreign analogues of steel 1066, 1566 and G15660 (USA), 66Mn4 and Ck67 (Germany), SUP6 (Japan), 080A67 (England) and 65Mn (China) with geometric shape and parameters according to GOST 1497-84 (ISO 6892-84) - the diameter of the working part is $10 \mathrm{~mm}$ and the length is $100 \mathrm{~mm}$. The chemical composition of sample material is determined by optical emission spectrometry on the instrument Q2 ION. The studies use active planning based on the plan of the full two-factor three-level experiment. Electromechanical hardening of the surfaces of the samples is carried out on a turning-screw-cutting machine 1M63 using an installation for electromechanical processing of parts of UEMO-standard machines. Hardness measurement of treated surfaces of HRC samples on Rockwell scale is performed according to the procedure GOST 9013-59 (ISO 6508-86) on the stationary press TR-5006. For sample preparation, the following were used: a metal cutting machine Labotom-5, a sample pressing plant for microstructural analysis CitoPress-5 and a polishing machine LaboPol-30. Microstructural analysis was performed at stage 1 at 50-fold magnification on an inverted METAM LV-34 metallographic microscope and at stage 2 at 500-fold magnification on an inverted metallographic microscope GX53F. The results are processed by mathematical statistics using multiple regression analysis. Research was carried out on the basis of laboratories for the restoration of worn-out parts and the study of the physical, mechanical and technological properties of metals and alloys of the Faculty of Engineering of Belgorod State Agricultural University.

From the practice of electromechanical processing of machine parts, it is known that the quality of hardening of samples is influenced by the following factors: 1) current intensity in the secondary winding $\left.I_{\mathrm{r}}=X_{1}[\mathrm{~A}] ; 2\right)$ the effort is in contact "the tool - a detail" $F_{\mathrm{k}}=X_{2}[\mathrm{~N}]$. As function of a response we accept: 1) hardness of the hardened surfaces $H R C=Y$ (on Rockwell's units) [5-7]. The range and intervals of variation of factors are taken taking into account the theoretical justification: 1) $X_{1}=I_{\mathrm{r}}=800 \ldots 1200 \mathrm{~A}$ with an interval $\left.\Delta I=200 \mathrm{~A} ; 2\right) X_{2}=F_{\mathrm{k}}=100 \ldots 300 \mathrm{~N}$ with interval $\Delta F=100 \mathrm{~N}$ [5-7]. The coding of experiments, factors and response functions are presented in Table 1. As a result of 9 triplicate tests, taking into account 3 control samples, 30 samples were made.

Table 1

\section{Orthogonal central composite plan of the experiment}

\begin{tabular}{|c|c|c|c|c|c|}
\hline \multirow{2}{*}{$\begin{array}{c}\text { No } \\
\text { test }\end{array}$} & \multicolumn{2}{|c|}{ Factors* } & \multicolumn{3}{c|}{ Response function } \\
\cline { 2 - 6 } & $\boldsymbol{X}_{\mathbf{1}}$ & $\boldsymbol{X}_{\mathbf{2}}$ & $\boldsymbol{Y}_{\mathbf{1}}$ & $\boldsymbol{Y}_{\mathbf{2}}$ & $\boldsymbol{Y}_{\mathbf{3}}$ \\
\hline 1 & + & - & $Y_{11}$ & $Y_{21}$ & $Y_{31}$ \\
\hline 2 & + & + & $Y_{12}$ & $Y_{22}$ & $Y_{32}$ \\
\hline 3 & - & + & $Y_{13}$ & $Y_{23}$ & $Y_{33}$ \\
\hline 4 & - & - & $Y_{14}$ & $Y_{24}$ & $Y_{34}$ \\
\hline 5 & 0 & - & $Y_{15}$ & $Y_{25}$ & $Y_{35}$ \\
\hline 6 & + & 0 & $Y_{16}$ & $Y_{26}$ & $Y_{36}$ \\
\hline 7 & 0 & + & $Y_{17}$ & $Y_{27}$ & $Y_{37}$ \\
\hline 8 & - & 0 & $Y_{18}$ & $Y_{28}$ & $Y_{38}$ \\
\hline 9 & 0 & 0 & $Y_{19}$ & $Y_{29}$ & $Y_{39}$ \\
\hline \multicolumn{7}{|l}{ * Signs “+," "-" and "0" - denote the upper, lower and base level of the factor } \\
\hline
\end{tabular}

The experimental part of the studies regarding electromechanical hardening of samples was carried out on the basis of a turning-screw-cutting machine 1M63 with the "UEMO-standard" installation in the following modes: spindle speed $-10 \mathrm{~min}^{-1}$, longitudinal (axial) tool supply $-1 \mathrm{~mm}$ per 1 revolution of the part.

In order to implement the methodology for substantiating the electromechanical hardening modes of machine parts, an algorithm for optimizing the values of mode parameters according to the maximum hardness criterion, presented in Fig. 1, was developed.

As a regression mathematical model of the dependence of the response function on the considered factors of the hardening process, we take the polynomial (1) of the second degree.

$$
Y=A_{0}+A_{1} \cdot X_{1}+A_{2} \cdot X_{2}+A_{3} \cdot X_{1}^{2}+A_{4} \cdot X_{1} \cdot X_{2}+A_{5} \cdot X_{2}^{2},
$$


where $A_{0} \ldots A_{5}$-empirical coefficients;

$X_{1}$ - current $I_{\mathrm{r}}$ on the reinforcing tool, A;

$X_{2}$ - tool pressing force $F_{\mathrm{k}}$ to the part, N;

$Y$ - sample surface hardness response function, HRC.

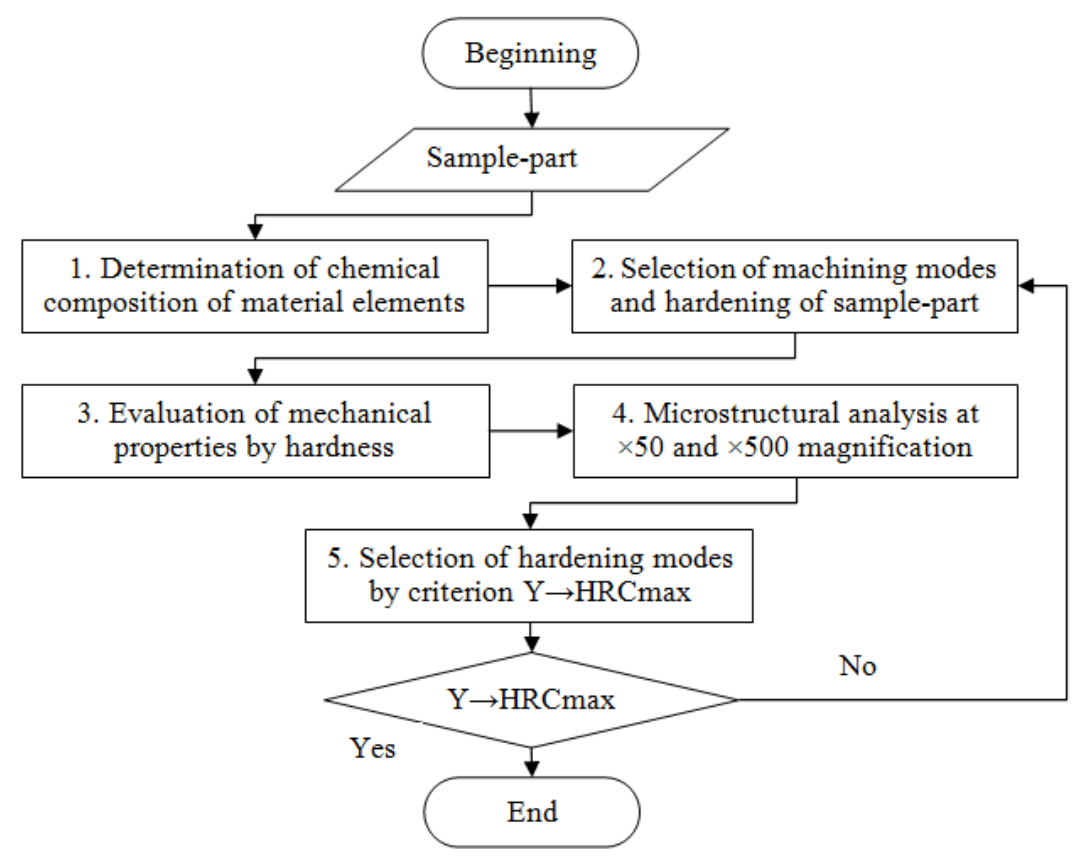

Fig. 1. Algorithm for optimization of hardening modes by criterion $\mathrm{Y} \rightarrow \mathrm{HRCmax}$

\section{Results and discussion}

In accordance with GOST 14959-2016 the chemical composition of steel 65G includes the following elements (\%): $\mathrm{C}-0.62 \ldots 0.70, \mathrm{Si}-0.17 \ldots 0.37, \mathrm{Mn}-0.70 \ldots 1.0, \mathrm{Cr}-$ not more than 0.15 , $\mathrm{Ni}$ - not more than $0.15, \mathrm{Cu}$ - not more than $0.20, \mathrm{P}$ - not more than $0.035, \mathrm{~S}$ - not more than 0.035 , content of $\mathrm{Mo}, \mathrm{Al}, \mathrm{Co}, \mathrm{Mg}, \mathrm{Nb}, \mathrm{Ti}, \mathrm{V}$ and $\mathrm{W}$ - is not normalized, and $\mathrm{Fe}$ is not normalized according to the content in the brand [8]. When studying the chemical composition of samples on a Q2 ION spectrometer, in order to confirm the steel grade, the Fe100 (approximate determination of the element content) and Fe110 (for low-alloy steels) methods were used. The results of the content of the elements in the test sample are given in Table 2.

Chemical composition of steel 65G sample

Table 2

\begin{tabular}{|c|c|c|c|c|c|c|c|c|c|}
\hline \multirow{2}{*}{ Method } & \multicolumn{10}{|c|}{ Mass fraction of element, \% } \\
\cline { 2 - 10 } & $\mathrm{C}$ & $\mathrm{Si}$ & $\mathrm{Mn}$ & $\mathrm{Cr}$ & $\mathrm{Ni}$ & $\mathrm{Cu}$ & $\mathrm{P}$ & $\mathrm{S}$ & $\mathrm{Fe}$ \\
\hline $\mathrm{Fe} 100$ & 0.897 & 0.301 & 0.804 & 0.034 & 0.124 & 0.230 & $<0.010$ & $<0.010$ & 97.40 \\
\hline $\mathrm{Fe} 110$ & 0.740 & 0.222 & 0.814 & 0.074 & 0.113 & 0.156 & $<0.003$ & $<0.003$ & 97.64 \\
\hline
\end{tabular}

Analysis of Table 2 data shows that according to the method $\mathrm{Fe} 100$ it is possible to argue that the grade of this sample is assigned to spring nonalloy steels $65,70,75,80,85,60 \mathrm{G}, 65 \mathrm{G}, 70 \mathrm{G}, 75 \mathrm{G}, 80 \mathrm{G}$ or $85 \mathrm{G}$ according to GOST 14959-2016. A comparative analysis of the data provided by Table 2 and GOST 14959-2016 shows that, in accordance with the method Fe110, it is possible to claim the coincidence of data on the content of elements relative to the steel grade $65 \mathrm{G}$, however, we note deviations in the carbon content $\mathrm{C}$ - by more than $5.7 \%$, and in the content of phosphorus $\mathrm{P}$ and sulfur $\mathrm{S}$ - we refer to the class of especially high-quality steel.

According to the procedure, a series of 27 samples were treated according to the experimental plan presented in Table 1. Mechanical properties were evaluated by hardness measurements before and after electromechanical hardening: indicators of descriptive statistics on hardness, HRC, before hardening are equal - average 14.78 , standard deviation 2.61 , dispersion 6.81 , coefficient of variation 0.18 ; after 
hardening - average 32.98, standard deviation 6.25, dispersion 39.05, coefficient of variation 0.19 [9]. Comparative analysis shows that the ratio of averages is 2.2 , the width of the curve taking into account the standard deviation of the sample after hardening is greater, while the dispersion also shows a large dispersion value of the hardness index relative to the average after hardening, the coefficients of variation are almost at the same level, i.e. the distributions of the index are approximately the same.

In order to identify structures and characteristics of electromechanical hardening modes, microstructural analysis of samples was carried out, which showed that a layer consisting of several zones was formed on the hardened surface of the sample: white (1), light non-flowing (2) and dark martensitic (3), passing into the ferrite-pearlite structure of the base (4). In particular, the following were investigated: the zone of the light and transition layer of the sample at $\times 50$ and $\times 500$ magnification (Fig. 2, $a, b$ ), where the transition zone with the needle structure is clearly distinguished, as well as a light layer (Fig. 3,a) with areas of origin of martensitic needles transforming into a ferrite-pearlite structure of a metal base (Fig. 3, $b$ ) [4; 9].

a)

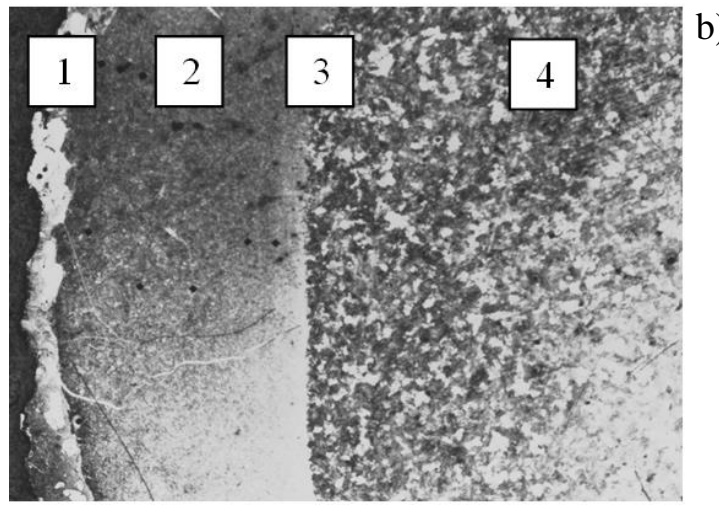

b)

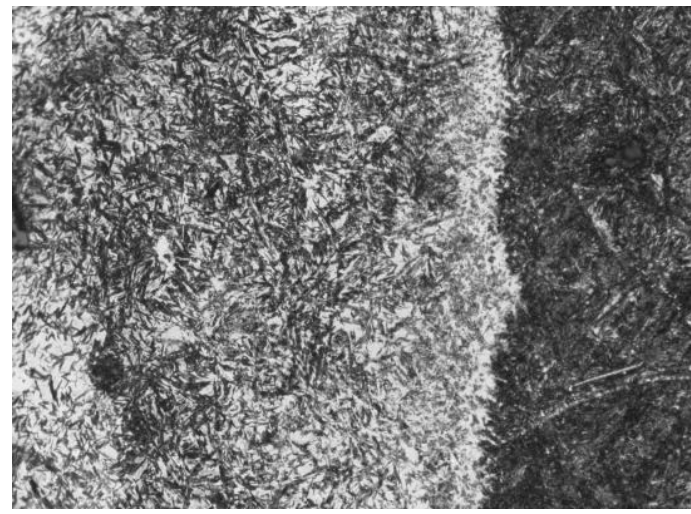

Fig. 2. Images of microstructures of steel 65G after hardening: $a$ - light layer and transition zone at $\times 50$ magnification; $b$ - light layer and transition zone at $\times 500$ magnification

a)

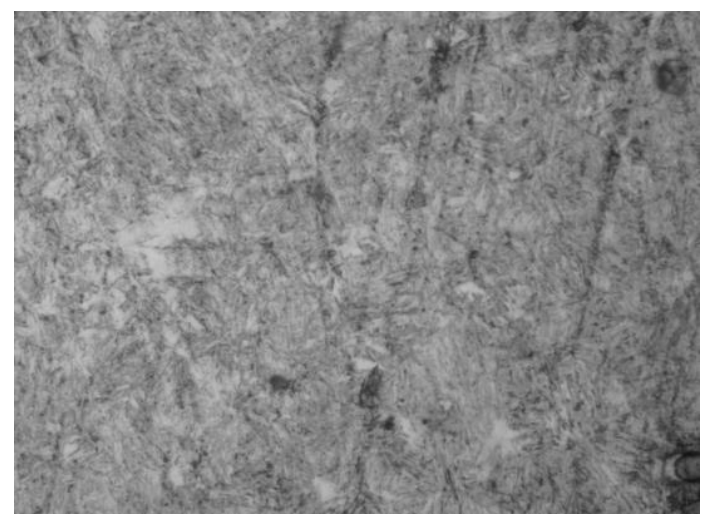

b)

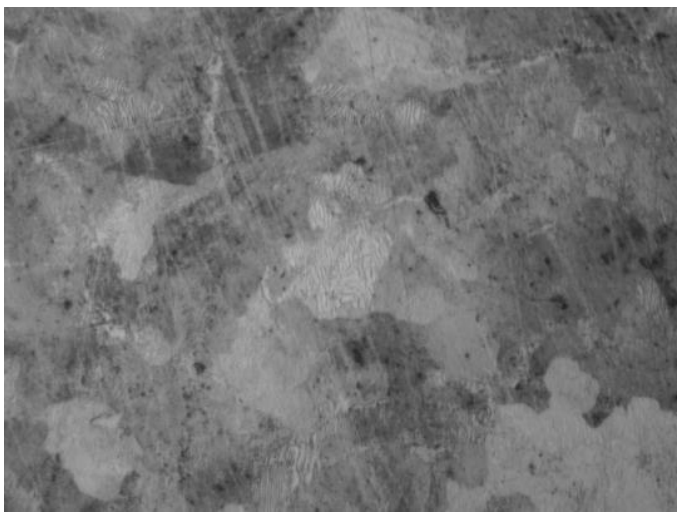

Fig. 3. Images of microstructures of steel $65 \mathrm{G}$ after hardening: $a-$ light layer at $\times 500$ magnification; $b$ - sample base at $\times 500$ magnification

The study of the influence of the current force and the force in the contact of the tool and the part on the mechanical properties by the hardness parameter of the surface hardened layer will be carried out on the basis of the empirical equation obtained using the technique of multiple regression analysis of experimental data in the form of equation (2).

$$
\begin{aligned}
& Y=-91.5237+0.2545 X_{1}-4.176 \cdot 10^{-2} \cdot X_{2}-1.3319 \cdot 10^{-4} \cdot X_{1}^{2}+ \\
& +1.2584 \cdot 10^{-4} \cdot X_{1} \cdot X_{2}-2.161810^{-4} X_{2}^{2},
\end{aligned}
$$

The empirical equation (2) is sufficiently defined by the Fisher criterion since $F_{\text {calc }}=2.762>F_{\text {table }}=2.685$ included variables with probability $P=0.95$, and a comparative analysis of the significance of coefficients according to the Student criterion shows a significant effect of current strength and a slight effect of the pressing force of the tool on the mechanical properties of hardened samples. 
By varying the values of the current in the range $X_{1}=I_{\mathrm{r}}=800 \ldots 1200 \mathrm{~A}$ with a pitch of $50 \mathrm{~A}$ and the pressing force in the range $X_{2}=F_{\mathrm{k}}=100 \ldots 300 \mathrm{~N}$ with a pitch of $50 \mathrm{~N}$ based on the empirical equation (2), we obtain a diagram of the effect of the current and the force on hardness (Fig. 4).

The theoretical solution of equation (2) based on the method of mathematical analysis under the criterion condition of tending to the maximum of the response function $Y \rightarrow \mathrm{HRCmax}$ made it possible to establish characteristic values of electromechanical hardening modes: current in the contact zone $X_{\text {lopt }}=I_{\mathrm{r}}=1060 \mathrm{~A}$ and tool pressing force $X_{\text {2opt }}=F_{\mathrm{k}}=210 \mathrm{~N}$. The coordinates of the points of optimal modes at maximum hardness are shown in Fig. 4.

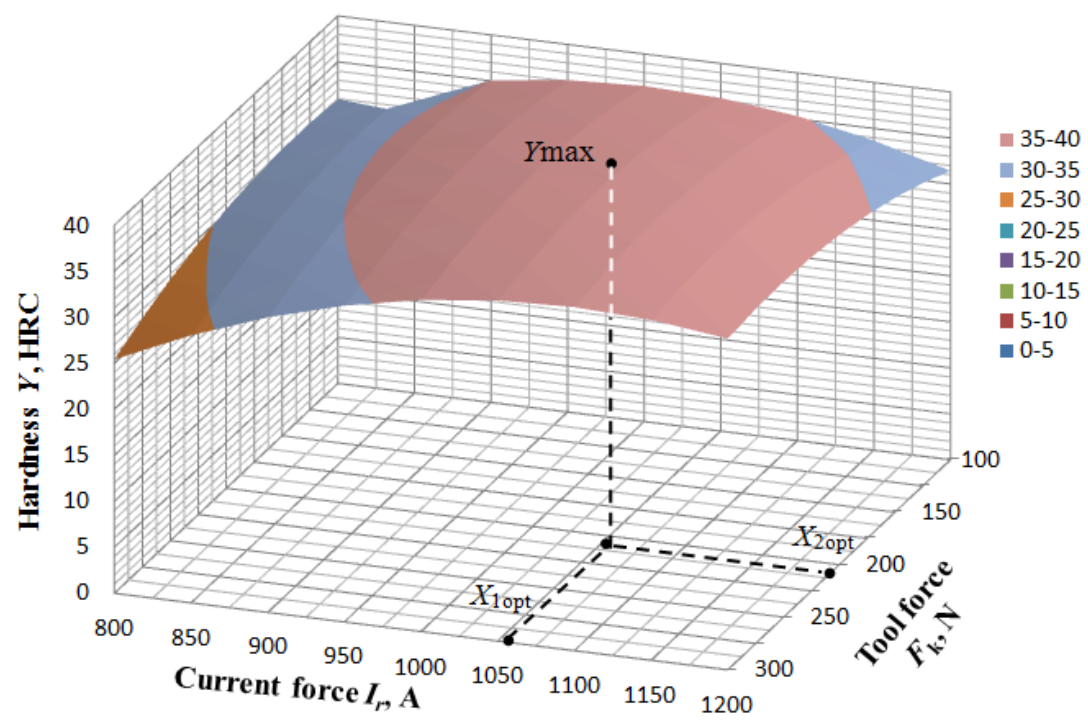

Fig. 4. Part hardness versus current and tool force diagram

An overview of research in the field of electromechanical processing of machine parts from medium and high-carbon steels showed that that as a result of electromechanical hardening, a white layer is formed on the surface; having non-uniform properties due to alternation of hardened and non-hardened structures [10], and during application of electromechanical coatings on the example of crankshaft main journals influence of preliminary and main processing modes is established [11], issues of improvement of quality of reducing coatings are proposed to be solved on the basis of subsequent electromechanical processing [12]. It should be noted that the mentioned studies did not carry out optimization of processing modes, which does not allow to realize potential level of mechanical properties of materials of parts taking into account their chemical composition. The proposed technique expands possibilities of substantiation of electromechanical processing modes in its various manifestations with access to optimization according to the criterion conditions of increasing operational properties, which are determined by composition and structure.

\section{Conclusions}

1. For the purpose of development of bases of technological process of electromechanical processing of discs of ploughshares made of steel $65 \mathrm{G}$ the algorithm of a technique of optimization of the modes of hardening by criterion of the maximum hardness on the example of cylindrical samples from steel $65 \mathrm{G}$ taking into account experimental assessment of the chemical composition, mechanical properties and microstructures of a detail is developed under a criteria condition of a maximum of hardness of a surface.

2. As a result of the analytical assessment of the chemical composition of the prototypes, it was established that the grades of the studied sample belong to spring nonalloy steels according to GOST 14959-2016, while quantitative analysis indicates belonging to the steel grade $65 \mathrm{G}$ of particularly high quality with an increased carbon content on $5.7 \%$.

3. The experimental evaluation of the mechanical properties of the samples according to hardness measurements shows an increase in hardness compared to the initial hardness before hardening by 2.2 times, which is insufficient in accordance with the technical requirements for the part. 
4. Microstructural analysis of sample slips shows that the observed microstructures do not fully correspond to those expected after electromechanical treatment of steel $65 \mathrm{G}$, martensite in the light zone is in the stage of origin, which must be taken into account when working out the process of hardening the cutting edges of the ploughshares.

5. As a result of the experimental development of the algorithm of the methodology for substantiating electromechanical hardening modes, the main factors of influence were revealed and disk processing modes were established. The prospects for further research are the implementation of the presented methodology directly on the ploughshares of sowing machines, taking into account the results obtained.

\section{References}

[1] Lamberson L.R., Kapur K.S. Reliability in engineering design. Weliy India Pvt. Limited, 2009. $608 \mathrm{p}$.

[2] Ханин М.В. Механическое изнашивание материалов: научное издание. М.: Издательство стандартов, 1984. 152 с. (Khanin M.V. Mechanical wear of materials: scientific publication. Moscow: Standards Publishing House, 1984. 152 p.) (In Russian).

[3] Пастухов А.Г., Кравченко И.Н., Волков М.И. Исследование износа дисковых сошников сеялки СЗТ-3,6А. Инновации в АПК: проблемы и перспективы. 2019. № 3 (23). С. 55-67. (Pastukhov A.G., Kravchenko I.N., Volkov M.I. Research of wear of disk coulters of the seeder SZT-3.6A. Innovations in the agro-industrial complex: problems and prospects. 2019. № 3 (23). pp. 55-67) (In Russian).

[4] Пастухов А.Г., Шарая О.А., Бережная И.Ш. Экспериментальные исследования режимов электромеханического упрочнения детали типа «плунжер». Труды ГОСНИТИ. 2017. Т.129. C. 148-157. (Pastukhov A.G., Sharaya O.A., Berezhnaya I.Sh. Experimental study of electromechanical modes of hardening of details of the «plunger». Trudy GOSNITI. 2017. V.129. pp. 148157). (In Russian).

[5] Erokhin M.N., Pastukhov A.G., Golubev I.G., Kazantsev S.P. Theoretical basis of justification of electromechanical hardening modes of machine parts. Engineering for rural development. Latvia University of Life Sciences and Technologies, Jelgava, 2020, Vol. 19, pp. 147-152.

[6] Kvon S.S., Kulikov V.Y., Filippova T.S. et al. Using high-chromium iron as material for production of the equipping components of mine shafts. Metalurgija (Zagreb, Croatia). 2016. T. 55. № 2. pp. 206-208.

[7] Морозов А.В., Кундротас К.Р. Повышение качества изготовления колесного цилиндра заднего тормоза автомобиля УАЗ применением поверхностного электромеханического дорнования. Инновации в АПК: проблемы и перспективы. 2018. № 4 (20). С. 11-18. (Morozov A.V., Kundrotas K.R. Improving the manufacturing quality of the wheel cylinder of the UAZ rear brake using surface electromechanical mandrel. Innovations in APK: problems and prospects. 2018. No 4 (20). pp. 11-18) (In Russian).

[8] Аскинази Б.М. Упрочнение и восстановление деталей машин электромеханической обработкой: монография. Москва: Машиностроение, 1989. 200 с. (Askinazi B.M. Hardening and reconditioning of machine parts electromechanical treatment. Moscow: Mashinostroenie, 1989. 200 p.) (In Russian).

[9] Kvon S.S., Kulikov V.Y., Shcherbakova Y.P. et al. Effect of inoculants introducing on improving ingot structure. Metallurgija (Zagreb, Croatia). 2019. T. 58. № 3-4. pp. 315-318.

[10] Dudkina N.G., Zakharov I.N. Micrononhomogeneous strain of the "white layer" produced by electromechanical treatment of a carbon steels. Mechanika. 2007. Nr.3(65). Pp. 17-21.

[11] Gorozhankina O.V., Kopylov Y.R., Zhirkov A.A. Peculiarities of heavy electro-mechanical plating on medium carbon steel 30 and 38 ChN3MA. MATEC Web of Conferences 129, 02004 (2017). Pp. 1-5. DOI: $10.1051 /$ matecconf/201712902004.

[12] Слинко Д.Б., Мурзаев В.П. Повышение качества покрытий с использованием последующей электромеханической обработки. Труды ГОСНИТИ. 2013. Т. 113. C. 395-399. (Slinko D.B., Murzaev V.P. Improvement of coating quality using subsequent electromechanical treatment. Trudy GOSNITI. 2013. V. 113. pp. 395-399) (In Russian). 